\title{
Aggregate stability affects carbon sequestration potential of different tropical soils
}

\author{
Leo Jude D. Villasica', Suzette B. Lina ${ }^{2 *}$ and Victor B. Asio ${ }^{2}$
}

\begin{abstract}
Aggregate stability and carbon (C) sequestration in soils are closely related phenomena. However, high aggregate stability does not always ensure high carbon sequestration to some soil types since other binding agents could dominate other than carbon. Thus, this study aimed to determine the relationship between aggregate stability and carbon sequestration of different tropical soils which basically differ in geology, genesis, and possibly in their dominant aggregating agents. The study selected four representative soil types (Haplic Acrisol, Calcaric Cambisol, Silic Andosol and Haplic Ferralsol) found in Leyte and Samar that were characterized by previous workers. Soil Organic Carbon (SOC) and Aggregate Stability (AS) in dry and wet conditions were quantified using standard procedures. Some pertinent secondary data were also recorded as reference for each soil type. Results revealed that only Silic Andosol showed positive significant correlation (0.93) between aggregate stability and soil organic carbon (SOC). The other soil types showed weak and negative correlation between aggregate stability and SOC; however, their stability revealed a strong positive relationship with inorganic binding agents. Therefore, each soil type reflects a different relationship between aggregate stability in wet condition and SOC and that the variations could be attributed to the differences in the morpho-physical and geochemical nature of the soils. Moreover, SOC is found to greatly influence the aggregate stability in Silic Andosol, thus the soil carbon sequestration potential of this soil type is generally related to its aggregate stability. However, in other soil types like Haplic Acrisol, Calcaric Cambisol, and Haplic Ferralsol, other binding agents like Calcium $(\mathrm{Ca})$ and iron oxides dominate and control the formation and stability of aggregates rather than SOC.
\end{abstract}

Keywords: Soil organic carbon, aggregate stability, soil carbon sequestration, soil types, Haplic Acrisol, Calcaric Cambisol, Silic Andosol, Haplic Ferralsol.

'Department of Agricultural Sciences, Caraga State University, Ampayon, Butuan City, 8600;

${ }^{2}$ Department of Soil Science, Visayas State University, VISCA, Baybay City, 6521-A, Philippines

\footnotetext{
* Corresponding Author. Address: Department of Soil Science, Visayas State University, Visca, Baybay City,6521-A, Philippines; e-mail:sblina@vsu.edu.ph DOI: $10.32945 /$ atr4016.2018
} 
Villasica, Lina \& Asio

\section{INTRODUCTION}

Aggregate stability and carbon sequestration in soils are closely related phenomena (Six et al 2004). In fact, the factors affecting aggregate stability are similar to those affecting the storage of carbon in soil which is generally recognized nowadays as sequestered carbon (Carter \& Stewart 1996, USDA 2008). Moreover, the stability of aggregates in some cases is directly related to the capacity of soils to sequester carbon (Onwerenadu et al 2010, Simansky 2012, Six et al 2004). However, it is increasingly recognized that high aggregate stability does not always ensure high carbon sequestration to some soil types since other binding agents are dominating other than carbon (Blanco-Canqui \& Lal 2004, Stockmann et al 2013).

Tropical island soils offer a diverse range of soil types from the poorlydeveloped to well-developed soils. Leyte and Samar in particular have a diverse range of soil types based on soil characterization researches conducted. In addition, it is suggested that these soils might be different from those in other humid tropical areas as a result of unique environmental factors influencing their formation (Asio et al 2006, Navarrete 2007, Sanchez 1976). Common soil types in the islands are under the soil orders Inceptisols, Andisols, Ultisols and Oxisols (Asio 1996, Asio et al 1998, Navarrete et al 2007, Navarrete et al 2008, Navarrete et al 2009, Maranguit \& Asio 2013). In connection to this, a rare opportunity of evaluating the relationship between aggregate stability and carbon sequestration under different soil types is possible which could be relevant in understanding the carbon dynamics in tropical island soils.

Thus, this study hypothesized that Leyte and Samar soils differ from other humid tropical areas in terms of geology, genesis, and development (Asio et al 2006) which probably includes aggregation processes. This means that between and among soil types, variation in their capacity to sequester carbon in an aggregate level is a function of aggregate stability. Moreover, the relationship between aggregate stability and carbon sequestration will differ among soil types. Therefore, the main goal of this study is to determine the SOC of different levels of aggregates and establish a relationship between aggregate stability and C sequestration of the selected soil types in Leyte and Samar. Furthermore, this study will provide relevant information regarding the function of tropical soils being a source or a sink of $C$ in an aggregate level and across soil types under reforestation and grassland land use.

\section{MATERIALS AND METHODS}

\section{Study Site Selection and Research Approach}

Four sites were selected; three of which were from the island of Leyte and one from the island of Samar (Figure 1). Previously characterized sites from Leyte and Samar were utilized in this study; hence, the characteristics and genesis of the soil type for each particular site was established already (Table 1). 
Aggregate stability affects carbon sequestration potential

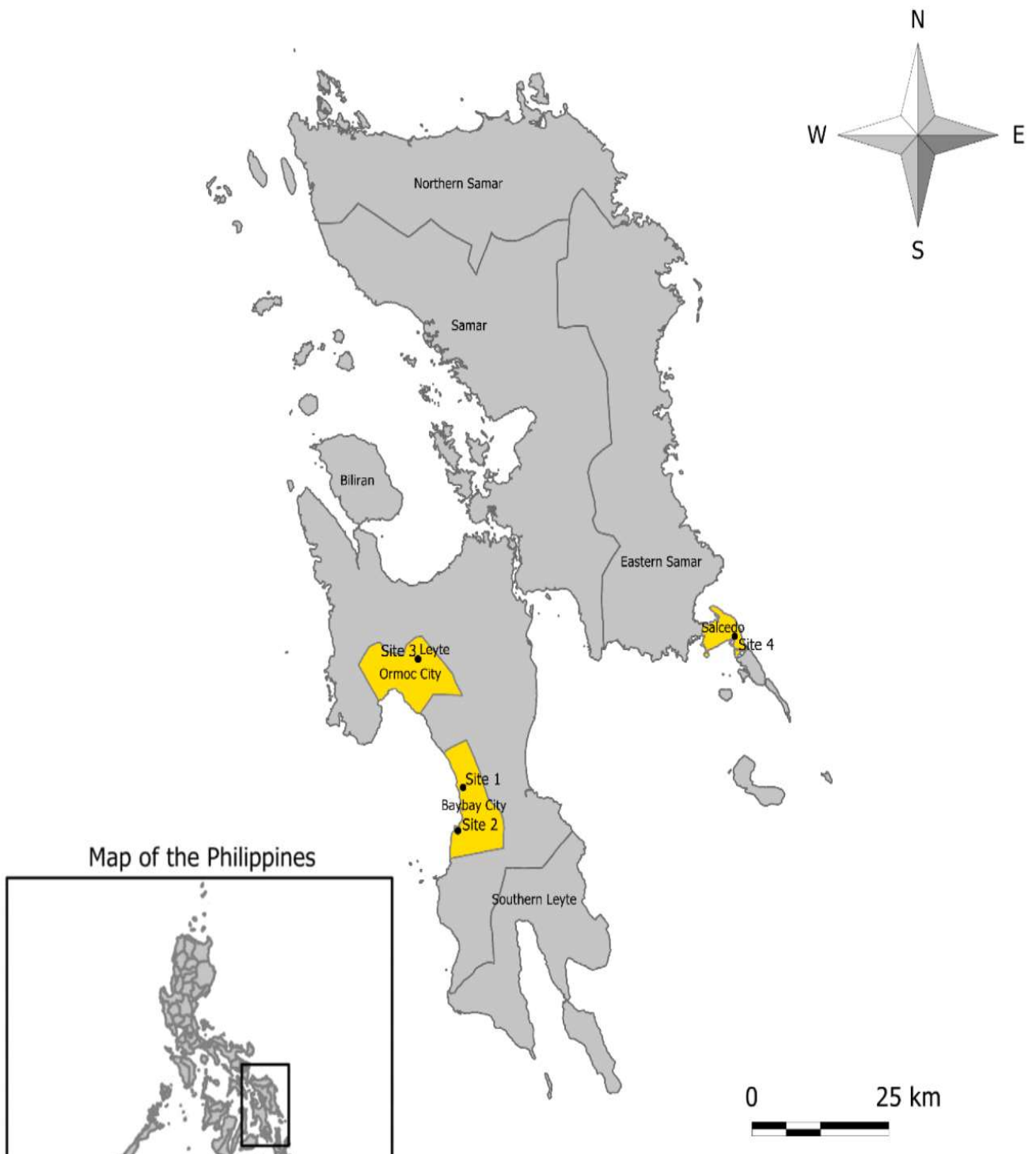

SCALE: $1: 1500000$

Figure 1. Map showing the site locations at Mt. Pangasugan (Site 1), Brgy. Punta (Site 2), Brgy. Milagro (Site 3), and Naparaan, Salcedo (Site 4) 
Briefly, the development stages of the soil studied range from the very young to very old, and these were from different parent materials. Two adjacent pits (approximately $50 \mathrm{~m}$ away) from each soil type were dug to one meter representing two different land uses (reforestation and grassland) according to the adjacent area approach of studying soils. The reforestation farm had varying stands: in Mt. Pangasugan and in Brgy. Punta, the reforestation areas were approximately 25 years while in Brgy. Milagro, Ormoc City and in Naparaan Salcedo, these were approximately $10-20$ years.

\section{Laboratory Methods}

Enough amount of soil samples were collected in each horizon from individual pits and were separated into four parts to satisfy some physical and chemical analysis. One quarter of the sample was air-dried for two days and sieved through a $2 \mathrm{~mm}$ mesh. The samples left were air-dried for one week in preparation for drysieving to collect aggregates of $>2,2-1,1-0.5,<0.5 \mathrm{~mm}$ size classes following the standard procedure. Thereafter, the desired physical parameters for each size class were done and the aggregates were pulverized and sieved through a $0.425 \mathrm{~mm}$ mesh screen in preparation for the chemical analyses. For physical parameters, bulk density was determined by Parrafin-clod method as outlined by Blake and Hartge (1986). Aggregate stability indices used were percentage dry aggregate size distribution, dry mean weight diameter, and aggregate stability in water where procedures and calculations were based on Kemper and Koch (1966). For the chemical analyses, soil pH was determined potentiometrically following the procedure outlined by ISRIC, (1995) and soil organic carbon per aggregate size was determined by wet-oxidation or the modified Walkley-Black method as outlined by Nelson and Sommers (1982).

Table 1. Site characteristics and soil classification

\begin{tabular}{|c|c|c|c|c|c|}
\hline Location & Coordinates & $\begin{array}{c}\text { Soil } \\
\text { Classification* }\end{array}$ & Texture & Relief & $\begin{array}{l}\text { Geological } \\
\text { Formation }\end{array}$ \\
\hline \multicolumn{6}{|c|}{ Site 1} \\
\hline $\begin{array}{l}\text { VSU, Visca, } \\
\text { Baybay City } \\
\text { Leyte* }\end{array}$ & $\begin{array}{l}10^{\circ} 44^{\prime} 41.12^{\prime \prime} \mathrm{N} \\
124^{\circ} 48^{\prime} 19.29^{\prime \prime} \mathrm{E}\end{array}$ & Haplic Acrisols & Clay & Hilly & $\begin{array}{l}\text { Late } \\
\text { Quaternary } \\
\text { Basaltic } \\
\text { Rocks }\end{array}$ \\
\hline \multicolumn{6}{|c|}{ Site 2} \\
\hline $\begin{array}{l}\text { Brgy. Punta, } \\
\text { Baybay City, } \\
\text { Leyte** }\end{array}$ & $\begin{array}{l}10^{\circ} 37^{\prime} 35.10^{\prime \prime} \\
\mathrm{N}, 124^{\circ} 47^{\prime} 16.91^{\prime \prime} \mathrm{E}\end{array}$ & $\begin{array}{r}\text { Calcaric } \\
\text { Cambisol } \\
\text { Site } 3\end{array}$ & Clay & Undulated & $\begin{array}{l}\text { Quaternary } \\
\text { Limestone }\end{array}$ \\
\hline 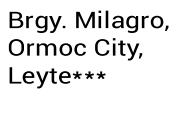 & $\begin{array}{l}11^{\circ} 5^{\prime} 41.50^{\prime \prime} \\
N, 124^{\circ} 39^{\prime} 52.90^{\prime \prime} \mathrm{E}\end{array}$ & Silic Andosol & $\begin{array}{l}\text { Clay } \\
\text { loam }\end{array}$ & Hilly & $\begin{array}{l}\text { Late } \\
\text { Quaternary } \\
\text { Volcanic } \\
\text { Rocks }\end{array}$ \\
\hline \multicolumn{6}{|c|}{ Site 4} \\
\hline 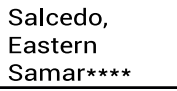 & $\begin{array}{l}11^{\circ} 8 ' 56.60^{\prime \prime} \\
N, 125^{\circ} 39^{\prime} 17.60^{\prime \prime} \mathrm{E}\end{array}$ & Haplic Ferralsol & $\begin{array}{l}\text { Silty } \\
\text { Clay }\end{array}$ & Undulated & $\begin{array}{l}\text { Ultramafic } \\
\text { rocks }\end{array}$ \\
\hline
\end{tabular}

*Soil classification is based on WRB (2006)

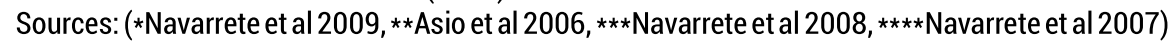


Aggregate stability affects carbon sequestration potential

\section{Data Analysis}

Secondary data were collated and referred if needed. The map was generated using the software Manifold System version 8.0. Statistical analysis particularly the correlations were done using the software SPSS version 17. Graphs and tables were made using Micro-soft Excel version 2013; the calculation of standard deviations was also done using the same program.

Table 2. Selected physical and chemical properties of the soils

\begin{tabular}{|c|c|c|c|c|}
\hline Soil Property & $\begin{array}{c}\text { Haplic } \\
\text { Acrisol* }\end{array}$ & $\begin{array}{c}\text { Calcaric } \\
\text { Cambisol** }\end{array}$ & $\begin{array}{c}\text { Silic } \\
\text { Andosol } * \star \star *\end{array}$ & $\begin{array}{c}\text { Haplic } \\
\text { Ferralsol } \star \star \star \star \star\end{array}$ \\
\hline Bulk density (g/cc) & $0.94-1.21$ & $1.44-1.5$ & $0.62-0.75$ & $0.89-1$ \\
\hline Clay $(g / k g)$ & $507-691$ & $440-520$ & $151-303$ & $158-690$ \\
\hline Silt (g/kg) & $117-225$ & $220-340$ & $405-463$ & $242-402$ \\
\hline Sand $(g / k g)$ & $165-354$ & $170-310$ & $144-319$ & $0-1$ \\
\hline SOC (bulk soil, \%) & $0.6-1.7$ & $0.4-4.1$ & $1.43-4.86$ & $0.1-1.38$ \\
\hline CEC (cmol/kg) & $11.1-19.5$ & $15.1-34.5$ & $9.21-20.46$ & $9.7-11.1$ \\
\hline $\mathrm{Fe}_{2} \mathrm{O}_{3}(\mathrm{~g} / \mathrm{kg})$ & $162-233$ & n.d & $124-135$ & $352-434$ \\
\hline $\mathrm{CaO}(\mathrm{g} / \mathrm{kg})$ & $2.1-13.6$ & $27-80$ & $7--11$ & $0.3-0.7$ \\
\hline $\mathrm{Fe}_{\mathrm{d}}(\mathrm{g} / \mathrm{kg})$ & $55-81.8$ & $4.7-12.9$ & $27.5-28$ & $180-194$ \\
\hline $\mathrm{Ca}(\mathrm{cmol} / \mathrm{kg})$ & $0.92-1.21$ & $63.55-77.35$ & $0.49-1.18$ & $0.39-3.57$ \\
\hline
\end{tabular}

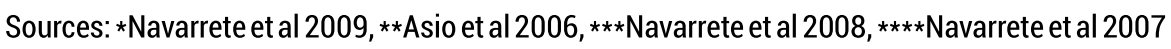

\section{RESULTS AND DISCUSSION}

\section{Soil and Physico-Chemical Characteristics}

The soils studied vary widely in terms of morphology, physical, and chemical characteristics (Figure 2 \& Table 2). In general, it belongs to soil orders, Ultisol, Cambisol, Andosol and Ferralsol. Specifically as classified by previous workers were Haplic Acrisol in Mt. Pangasugan (Navarrete et al 2009), Calcaric Cambisol in Brgy. Punta (Asio et al 2006), Silic Andosol in Brgy. Milagro (Navarrete et al 2008) 
and Haplic Ferralsol in Naparaan, Salcedo (Navarrete et al 2007) respectively (Table 1). Physical and chemical characteristics of the soils also differ widely (Table 2). For example, bulk density was very low in Silic Andosol while it was relatively higher in Calcaric Cambisol. This is because the latter revealed relatively high amount of $\mathrm{Ca}$ and $\mathrm{CaCO}_{3}$ which is known as good cementing agent to soils while the former was dominated by amorphous minerals which is generally friable and structureless. Moreover, Haplic Acrisol and Haplic Ferralsol revealed a thick profile implying advanced weathering stage; however, the former shows argillic subsurface horizon as indication of high clay accumulation while the latter shows oxic subsurface horizon since it has a relatively higher accumulation of Fe within.

\section{Aggregate Distribution and Stability of Different Soil Types}

Figure 3 shows the percentage size distribution of aggregates in different soil types. The size distribution of aggregates was very variable. In general, $>2 \mathrm{~mm}$ aggregates were decreasing down the profile and the other sizes were consequently increasing except for Calcaric Cambisol (Figure 3B). This indicates that at the surface horizons, bigger aggregates dominate since most of the binding agents were partially decomposed organic matter, root exudates, and fungal hyphae. These binding agents according to the concept of aggregate hierarchy in soils bind aggregates into sizes greater than $2 \mathrm{~mm}$ (Tisdall \& Oades 1982). Other binding agents such as oxides of $\mathrm{Fe}$,
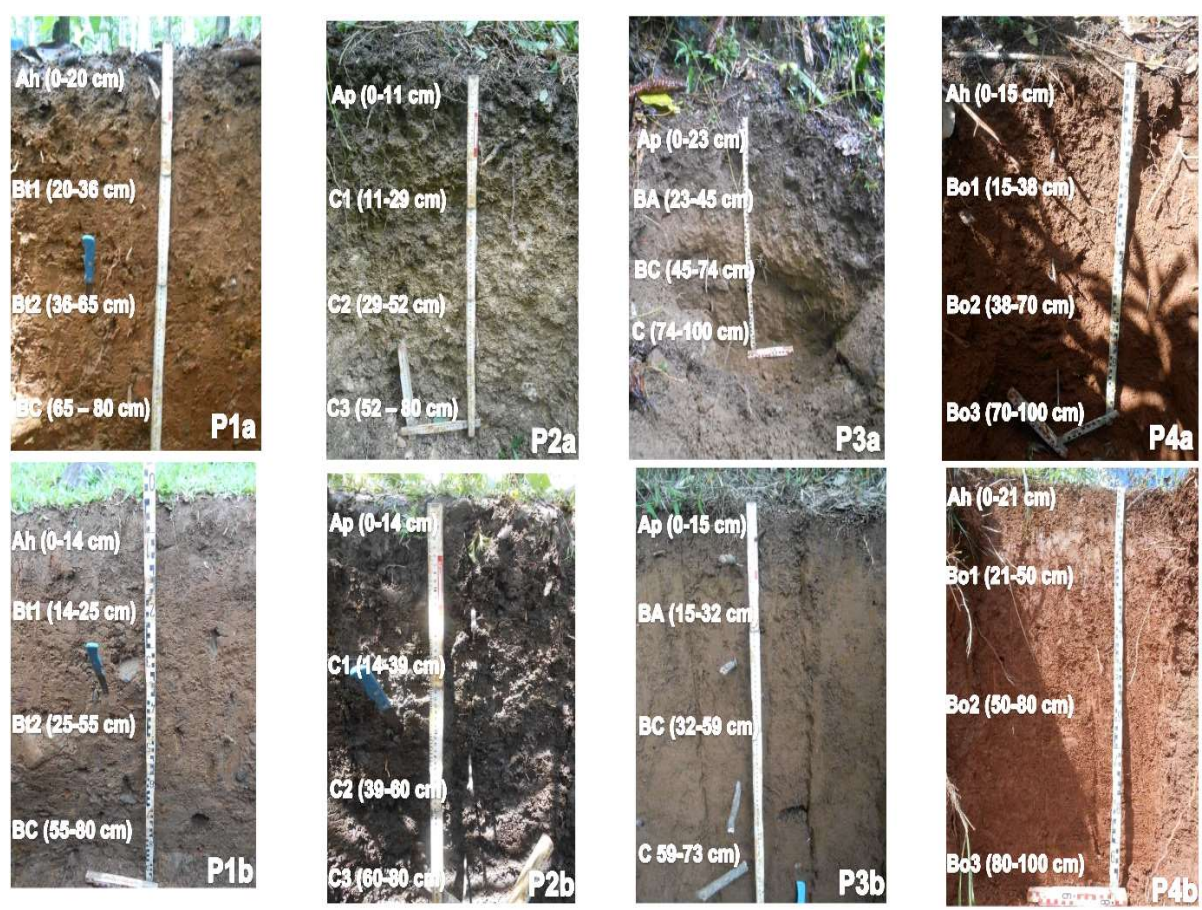

Figure 2. Photographs showing the profile of different soil types (P1, P2, P3, P4: Haplic Acrisol, Calcaric Cambisol, Silic Andosol, Haplic Ferralsol) under reforestation (a) and grassland (b) 
Aggregate stability affects carbon sequestration potential

and humus bind aggregates to sizes less than $2 \mathrm{~mm}$ which is high in the lower horizons of the soil; thus, the dominance of $<2 \mathrm{~mm}$ sizes in the lower horizons. In the case of Calcaric Cambisol, $\mathrm{Ca}$ forms and some humus could influence the formation of bigger aggregates throughout the profile. In fact, studies conducted in this soil type primarily of characterization assumed that the better stability of this soil could be attributed to the high $\mathrm{CaCO}_{3}$ acting as cement between and among soil particles (Asio et al 2006). Also, the variation in sizes could be attributed to the differences in land uses. The distribution of aggregates could indicate the structural architecture of the soil which also further implies the soil's structural stability. The higher the percentages of bigger aggregates by weight would mean better stability of the soil (Carter \& Stewart 1996).

Dry aggregate stability as indicated by dMWD is shown in Table 3. Among soil types, Calcaric Cambisol showed a relatively higher amount of dMWD followed by Haplic Acrisol, Haplic Ferralsol and lastly, Silic Andosol. These indicate that Calcaric Cambisol was more stable and Silic Andosol was the least stable in dry condition. The bigger aggregates that dominate in Calcaric Cambisol could be due to the presence of high amount of $\mathrm{Ca}$ and $\mathrm{CaCO}_{3}$ (Asio et al 2006) which is noted to participate in the binding for this soil type (Six et al 2004). On the other hand, the amorphous nature (Navarrete et al 2008) of Silic Andosol could be the reason of poor aggregation of this soil type since this mineral is generally not crystallized and thus, results to formation of smaller aggregates (Huygens et al 2005).

Moreover, stability of soil aggregates against the forces of water was shown in Figure 4. In general, aggregate stability in water did not differ widely across aggregate fractions but differed among soil types: Sylic Andosol showed relatively fractions however, differ among soil types, Silic Andosol showed relatively lesser stability in wet condition. Regarding aggregate stability with size, smaller aggregates in Silic Andosol showed higher stability. This could be due to the effect of humus and other binding agent responsible in forming smaller aggregates which is known to be prominent in this soil type (Huygens et al 2005). The relatively higher stability of Haplic Acrisol, Calcaric Cambisol and Haplic Ferralsol could be due to other soil properties such as bulk density and other binding agents as suggested in previous studies of similar soil types (Igwe et al 2013, Six et al 2004) since SOC might slightly participate in aggregation since it was generally low in this soil types based primarily in bulk soil (Table 2). 
Villasica, Lina \& Asio

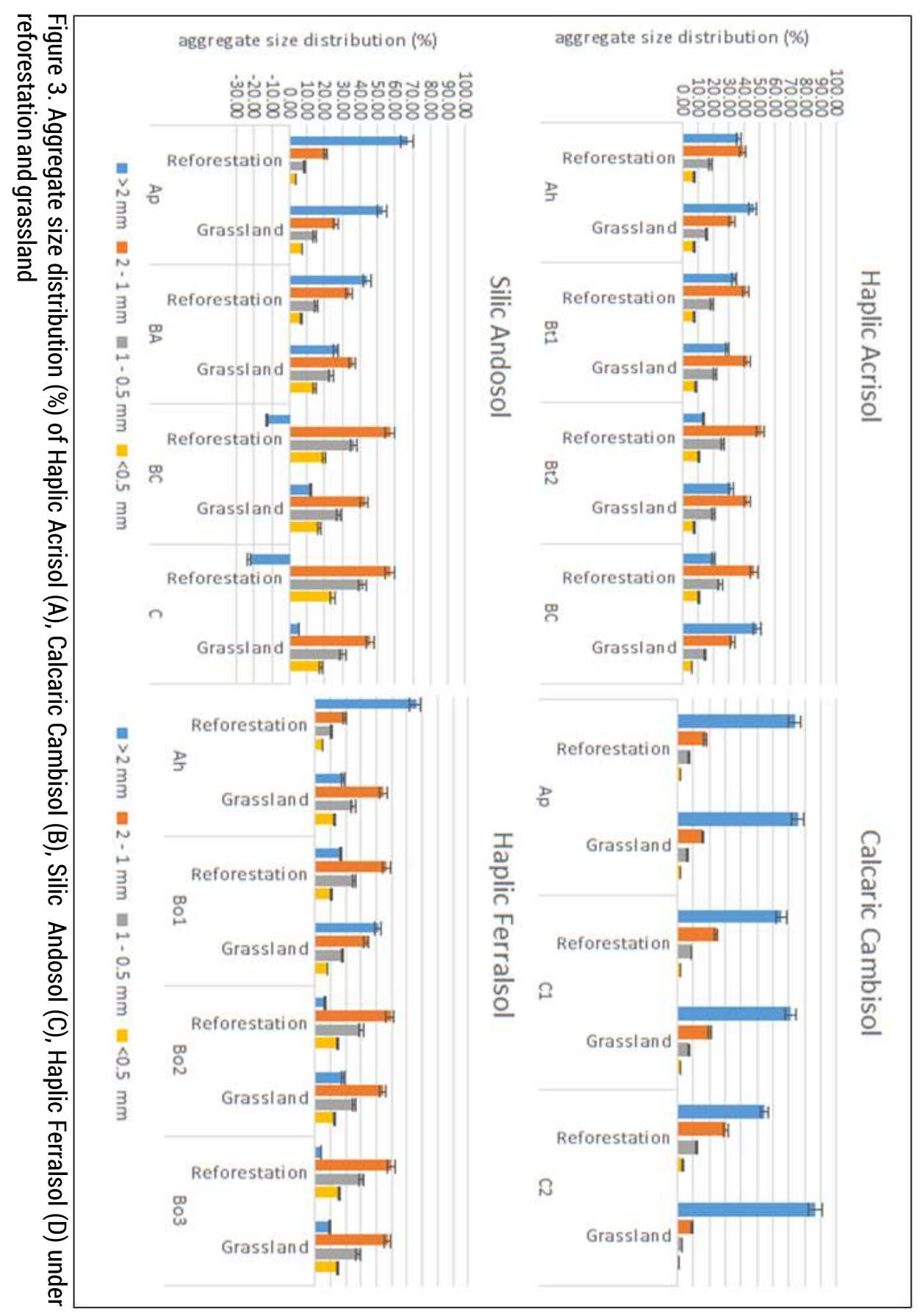


Aggregate stability affects carbon sequestration potential

Table 3. Bulk density and dry mean weight diameter of different soil types in Leyte and Samar

\begin{tabular}{|c|c|c|c|c|c|}
\hline \multirow[t]{2}{*}{ Soil Type } & \multirow[t]{2}{*}{ Horizon } & \multicolumn{2}{|c|}{ Bulk density $\left(\mathrm{g} \mathrm{cm}^{-3}\right)$} & \multicolumn{2}{|c|}{$\mathrm{dMWD}(\mathrm{mm})$} \\
\hline & & Reforestation & Grassland & Reforestation & Grassland \\
\hline \multirow[t]{4}{*}{ Haplic Acrisol } & Ah & 1.32 & 1.41 & 2.00 & 2.20 \\
\hline & Bt1 & 1.29 & 1.42 & 1.94 & 1.81 \\
\hline & Bt2 & 1.47 & 1.51 & 1.44 & 1.89 \\
\hline & $B C$ & 1.17 & 1.44 & 1.60 & 2.29 \\
\hline SD & & & & 0.27 & 0.23 \\
\hline \multirow[t]{3}{*}{ Calcaric Cambisol } & $A p$ & 1.47 & 1.35 & 2.94 & 2.89 \\
\hline & $\mathrm{Cl}$ & 1.34 & 1.51 & 2.85 & 2.72 \\
\hline & $\mathrm{C2}$ & nd & 1.44 & 3.20 & 2.46 \\
\hline SD & & & & 0.18 & 0.22 \\
\hline \multirow[t]{4}{*}{ Silic Andosol } & $A p$ & 0.62 & 0.62 & 2.73 & 2.35 \\
\hline & $A B$ & 0.69 & 0.69 & 2.18 & 1.67 \\
\hline & BA & 0.70 & 0.70 & 0.73 & 1.32 \\
\hline & $B C$ & 0.75 & 0.75 & 0.42 & 1.16 \\
\hline SD & & & & 1.12 & 0.53 \\
\hline \multirow[t]{4}{*}{ Haplic Ferralsol } & Ah & 0.90 & 0.89 & 2.67 & 1.52 \\
\hline & Bol & 0.90 & 0.89 & 1.51 & 2.08 \\
\hline & Bo2 & 0.90 & 0.90 & 1.21 & 1.51 \\
\hline & Bo3 & 1.00 & 1.00 & 1.15 & 1.30 \\
\hline SD & & & & 0.71 & 0.33 \\
\hline
\end{tabular}

SD - Standard Deviation of means within column

SOC distribution within aggregate sizes of different soil types

Figure 5 shows the distribution of SOC within aggregates. In general, results showed that the bulk of soil organic carbon was observed in A horizon and down the profile, SOC decreases. Moreover, considering the sizes, the distribution of SOC was more concentrated in aggregates sizes lesser than $2 \mathrm{~mm}$ in all horizons in Haplic Acrisol (Figure 5A). A similar trend was also observed for the other three soil types. Regarding the amount of SOC within aggregates, the highest value was found in Silic Andosol. Present result confirmed those findings of Navarrete et al (2008), in which this soil had generally high OM content. In fact, Lal (2008) calculated the global soil carbon storage and found that Andosols had high amount of organic carbon but not higher than Mollisols and other organic soils. 
Villasica, Lina \& Asio

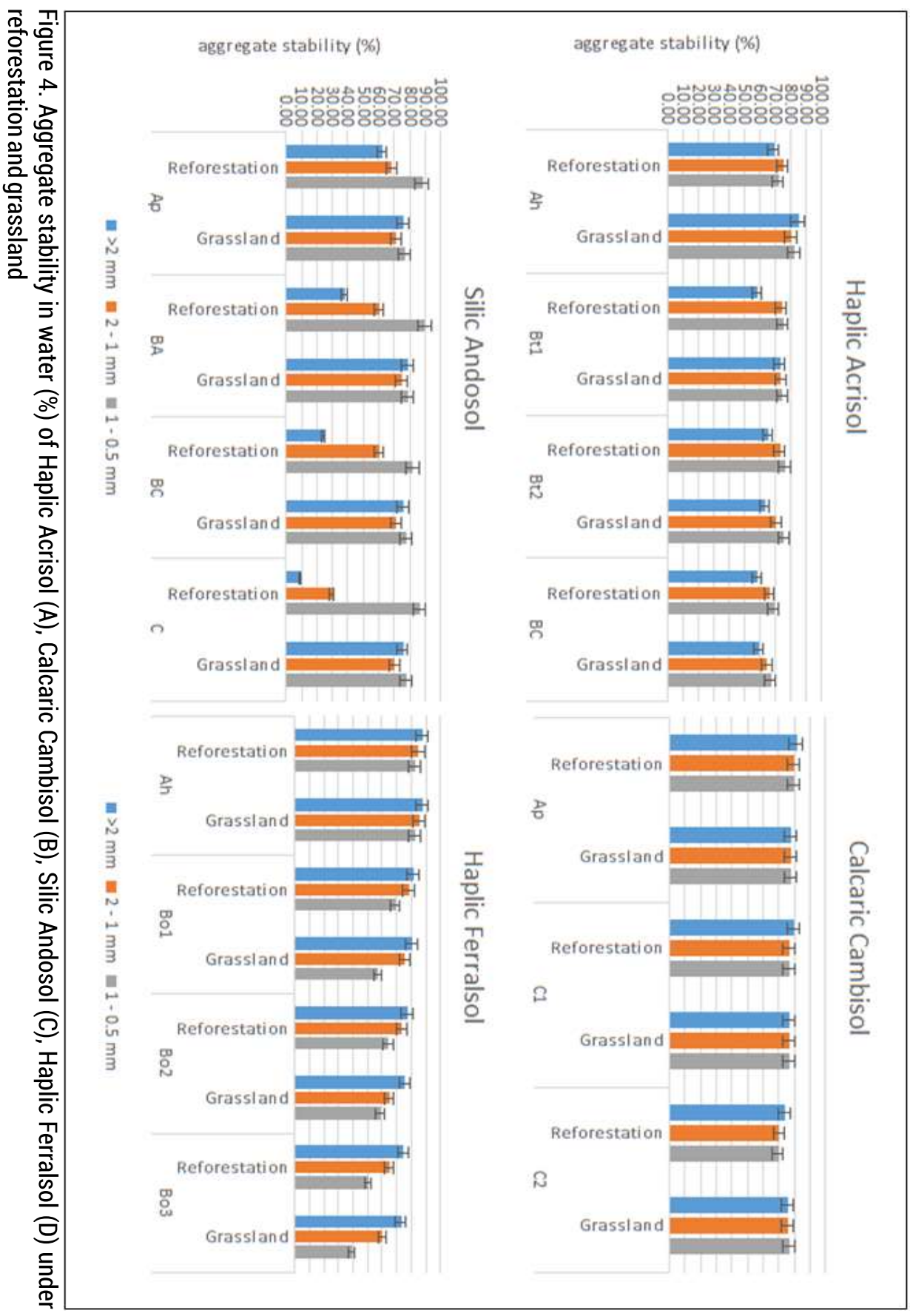


Aggregate stability affects carbon sequestration potential

Moreover, among soil types, SOC content was relatively lower in Haplic Acrisol, Calcaric Cambisol and Haplic Ferralsol than in Silic Andosol. Generally, Andosols contain high amount of SOC since in the formation of this soil type, SOC acts as ligand forming metal-humus complexes which in turn builds up the aggregates; hence, the profile is developed (Huygens et al 2005). Other studies on Andosol such as of Asio et al (1999), Lal (2004) and Navarrete et al (2008) indicated that $\mathrm{SOC}$ contents of this soil is generally high. The relatively lower content of SOC for the other soil types could be attributed to the nature of these soils, particularly in Haplic Acrisol and Haplic Ferralsol which was noted to have undergone extensive weathering (Navarrete et al 2007, Navarrete et al 2009, WRB 2006) thus, SOC degradation might also be expected. Asio et al (2009), reviewed the soil degradation in Leyte Island and reported the occurrence of highly weathered soils in the area and that these soils were generally degraded and low in organic matter (OM); thus, SOC would be low also. Moreover, Calcaric Cambisol, which is basically a poorly developed soil, is expected to have a relatively lower SOC content since it has thinner profile and the accumulation of OM is limited by age (WRB 2006). On the other hand, it was generally observed in the present study that the cumulative SOC in different aggregates sizes in each horizon was higher than the SOC findings of the previous studies which used bulk soil in each horizon in all soil types.

\section{Aggregate Stability in Water and its Controlling Factors in Different Soil Types}

In the tropics, precipitation generally exceeds evapotranspiration; thus, excess water could either percolate within the soil or run-off the surface. In this case, aggregate degradation of the tested soils could primarily be due to slaking and shearing due to the forces of water (Mbagwu 2003). Thus, the correlation presented in Table 4 associated aggregate stability in wet condition and the possible factors controlling it.

In Haplic Acrisol, aggregate stability in water positively correlates with size class, bulk density, dMWD, SOC, $\mathrm{FeO}, \mathrm{CaO}, \mathrm{Ca}$ ions. However, among positive correlations, size class, $\mathrm{FeO}$ and $\mathrm{Ca}$ revealed significant correlations with aggregate stability, which implies that in this soil type, bigger aggregates would mean better stability and the dominant binding agents would be $\mathrm{FeO}$ and $\mathrm{Ca}$ ions. Moreover, size class negatively correlates with $\mathrm{SOC}$ as well as aggregate stability in water with Fed (crystalline form) which indicates that SOC content increases with decreasing size class and Fed is indirectly related to the aggregates stability in water for this soil. These results generally coincide with the findings of Igwe et al (2013) who worked on similar soil type. They emphasized that for this soil type, oxides of iron generally control the aggregate stability both in dry and wet conditions. Also, Six et al (2004) reviewed the link among aggregation and its controlling factors and recognized the participation of different forms of $\mathrm{Fe}$ in the stability of aggregates particularly in highly weathered soils. 
Villasica, Lina \& Asio

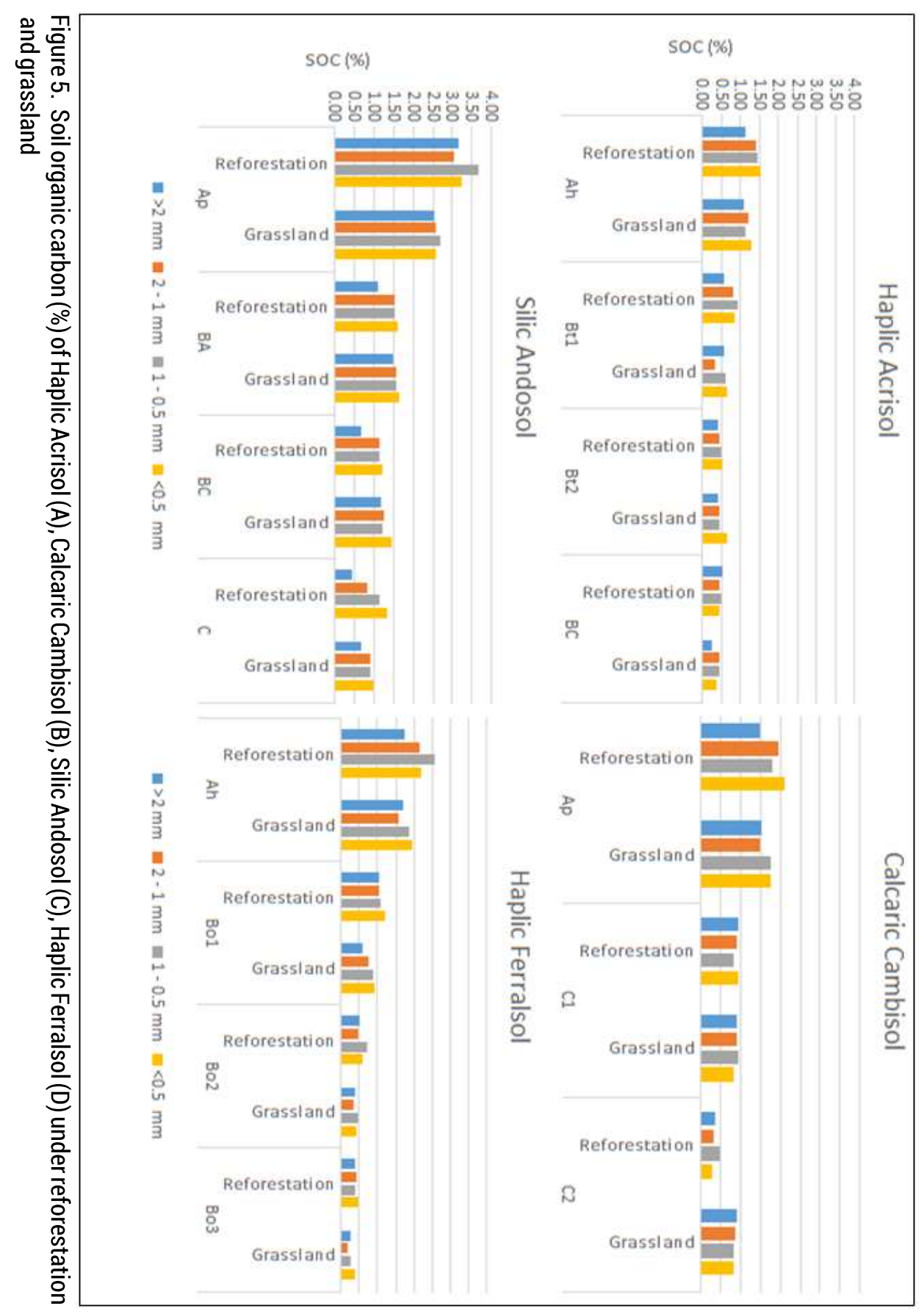


Aggregate stability affects carbon sequestration potential

It was generally observed that in Calcaric Cambisol (Table 4), aggregate stability in water positively correlates with size class, dMWD, FeO, Fed, Ca ions and negatively correlates with bulk density, SOC, and $\mathrm{CaO}$. Results indicate that the aggregation for this soil type was generally controlled by its chemical properties other than SOC. Asio et al (2006) suggested that the moderate to strong structure grade of this soil type could be due to the combined effects of humus, $\mathrm{Ca}$ and $\mathrm{CaCO}_{3}$. In addition, a review indicated that $\mathrm{Ca}$ ions and $\mathrm{CaCO}_{3}$ were outstanding in cementing soil particles but the degree of importance depends on soil type (Six et al 2004).

On the other hand, in Silic Andosol, it was found that aggregate stability in water positively correlates with dMWD, SOC, $\mathrm{CaO}$, and $\mathrm{Ca}$ while it shows negative correlation with size class, bulk density, FeO, and Fed. Among positive correlations, aggregate stability was significantly correlated with dMWD and SOC. This means that more stable aggregates were in the smaller sizes $(<1 \mathrm{~mm})$ and the dominant binding agent was SOC. Moreover, among negative correlations, aggregate stability was inversely related to increasing compaction as well as FeO contents. In addition, size class shows negative correlation with SOC which implies that higher SOC was noted in smaller aggregates for this soil type. The strong dependence of aggregate stability with SOC is supported by Huygens et al (2005) that for Andosols, aggregation is generally controlled by SOC that when organic materials were applied to this soil, aggregate stability was enhanced.

Consequently, in Haplic Acrisol, aggregates stability in water positively correlates with size class, dMWD, $\mathrm{FeO}$, and $\mathrm{Ca}$. and a weak correlation was observed with $\mathrm{CaO}$. These results further indicate that stable aggregates were common in bigger aggregates. Moreover, the main binding agent responsible for its aggregation were the iron oxides and $\mathrm{Ca}$ ions. Meanwhile, aggregate stability in water for this soil type negatively correlates with bulk density, SOC, and Fed contents. These findings generally confirmed Navarrete et al (2007) who suggested that better structure formation of Haplic Acrisol could be due to the oxides of iron from which they quantify to be high among other forms of iron in this soil type.

\section{Relationship Between Aggregate Stability and Carbon Sequestration of Different Soil Types}

The soils investigated differ widely in terms of physical and chemical properties (Table 2). Thus, this variability could influence the relationship between aggregate stability and carbon sequestration among soil types. In soils, SOC contents could directly mean soil carbon sequestration (Lal 2008) and since a significant positive correlation was observed between aggregate stability and SOC in Silic Andosol, it could be suggested that carbon sequestration is directly related to its aggregate stability. Huygens et al (2005) emphasized that in the formation of Andosols, soil organic matter acts as ligand or bridge in binding soil particles into aggregates or peds; therefore, the decline of SOC content would also reduce the stability of soils. 
Table 4. Correlation coefficients among size class, dMWD, aggregate stability in water, $\mathrm{SOC}$, and common inorganic binding agents

\begin{tabular}{lcccc}
\hline & Haplic Acrisol & $\begin{array}{c}\text { Calcaric } \\
\text { Cambisol }\end{array}$ & $\begin{array}{c}\text { Silic } \\
\text { Andosol }\end{array}$ & $\begin{array}{c}\text { Haplic } \\
\text { Ferralsol }\end{array}$ \\
\hline AS * Size & $0.827^{*}$ & 0.418 & -0.567 & $0.868^{* *}$ \\
AS * BD & 0.83 & -0.731 & $-0.949^{*}$ & -0.795 \\
AS * dMWD & 0.349 & 0.444 & $0.947^{*}$ & $0.96^{*}$ \\
Size * SOC & -0.598 & -0.608 & $-0.809^{*}$ & -0.445 \\
AS * SOC & 0.317 & -0.403 & $0.93^{* *}$ & -0.236 \\
AS * Fe2O & $0.915^{*}$ & $n . d$ & $-0.957^{*}$ & $0.99^{* *}$ \\
AS* CaO & 0.891 & -0.812 & 0.852 & 0.487 \\
AS * Fed & -0.222 & 0.936 & -0.385 & -0.554 \\
AS * Ca & $0.997^{* *}$ & 0.852 & 0.682 & $0.914^{*}$ \\
\hline
\end{tabular}

*correlation is significant at 0.05 level

**correlation is significant at 0.01 level

AS - Aggregate stability, Size - Size class, SOC - soil organic carbon, BD - Bulk density, dMWD - dry mean weight diameter

$\mathrm{Fe}_{2} \mathrm{O}_{3}, \mathrm{Ca}_{2} \mathrm{O}_{3}$, and $\mathrm{Fe}_{\mathrm{d}}, \mathrm{Ca}^{+}$- secondary data (see. Table 2)

However, in Haplic Acrisol, Calcaric Cambisol and Haplic Ferralsol, the relationship between aggregate stability and carbon sequestration was weak. This means that other binding agents might as well participate in the stability of aggregates and that the carbon sequestration potential of these soil types cannot be approximated by its aggregate stability. In addition, it was found that in these soil types, a significant positive correlation was observed between aggregate stability and inorganic binding agents such as oxides of $\mathrm{Fe}$ and $\mathrm{Ca}$ and crystalline $\mathrm{Fe}$ and $\mathrm{Ca}$ ions. Present study coincides with the findings of earlier studies with similar soils (Igwe et al 2013, Lawal et al 2010, Six et al 2004). 
Aggregate stability affects carbon sequestration potential

\section{Soil Carbon Stock Assessment under Reforestation and Grassland across Soil Types}

SOC is directly related to soil carbon sequestration (Lal 2008). Sequestration is commonly used since it implies the process of capturing the $\mathrm{C}$ by plants and stored in soils and its loss through microbial decomposition. The present study includes the quantification of stored carbon in different soil types. A relatively high SOC was observed under reforestation than in grassland in all soil types except in Calcaric Cambisol (Table 5). The reforestation area was established for about 20 to 25 years ago; thus, the high accumulation of SOC in this area was observed. In addition, studies on the accumulation of $\mathrm{SOC}$ in the reforestation area resulted to increasing carbon content through time (Blanco-Canqui \& Lal 2004, Epron et al 2009, Lal 2005, Marin-Spiotta et al 2008, Veldkamp 2003). The relatively higher SOC in grassland of Calcaric Cambisol could be due to the high rooting density associated with grasses which had generally high OM turnover rate into the soil (Percival et al 2000)

In terms of potential loss via aggregate degradation, results suggested that Silic Andosol tends to be more susceptible to SOC losses due to very unstable aggregates even with high SOC contents. Thus, physical and biochemical protection of carbon in Silic Andosol would be minimal due to this relationship. On the other hand, though the other soil types had higher aggregate stability, their SOC content is relatively lower implying a lesser net carbon sequestration and the chemical stabilization of carbon by other binding agent could help preserve SOC in the long run (Lal 2010, Six et al 2004).

Table 5. Soil organic carbon (tons $\mathrm{Cha}^{-1}$ ) under forest and grassland as affected by soil typesecondary data (see. Table 2)

\begin{tabular}{lrr}
\hline & Forest & Grassland \\
\hline Haplic Acrisol & 318.73 & 263.58 \\
Calcaric Cambisol & 203.99 & 330.34 \\
Silic Andosol & 426.02 & 297.96 \\
Haplic Ferralsol & 305.69 & 295.23 \\
\hline
\end{tabular}

\section{CONCLUSIONS}

In conclusion, each soil type reflects a different relationship between aggregate stability in wet condition and $\mathrm{SOC}$ and the variations could be attributed to the differences in the morpho-physical and geochemical nature of the soils. Moreover, SOC is found to greatly influence the aggregate stability in Silic Andosol; thus, the soil carbon sequestration potential of this soil type is generally related to its aggregate stability. For the other soil types such as Haplic Acrisol, Calcaric Cambisol, and Haplic Ferrarsol, carbon sequestration is low as observed by low $\mathrm{SOC}$ values since other binding agents dominate and control the formation and stability of aggregates. 
Villasica, Lina \& Asio

\section{ACKNOWLEDGMENT}

The authors are thankful to the Department of Science and Technology (DOST) for awarding the first author (Mr. LJD Villasica) an Accelerated Science and Technology Human Resource Development Program (ASTHRDP) - National Science Consortium graduate scholarship that made his MSc studies and graduate thesis (on which this paper was based) possible. The following members of the Graduate Advisory Committee are also thanked for their comments and suggestions on the thesis manuscript: Dr. Marlito Jose M. Bande (Tropical Ecology).

\section{REFERENCES}

Asio VB. 1996. Characteristics, weathering, formation, and degradation of soils from volcanic rocks in Leyte, Philippines, 33. Hohenheimer Bodenkundliche Hefte, Stuttgart, Germany.

Asio VB, Jahn R, Stahr K \& Margraf J. 1998. Soil of the tropical forest of Leyte, Philippines: impact of different land uses on status of organic matter and nutrient availability (pp38-44). Springer-Verlag Berlin, Heilderberg, New York City.

Asio VB, Jahn R \& Stahr K. 1999. Changes in the properties of a volcanic soil (Andisol) in Leyte due to conversion of forest to other land uses. Philippine $J$ Science, 128(1):1-13.

Asio VB, Cabunos Jr CC \& Chen ZS. 2006. Morphology, physiochemical characteristics, and fertility of soils from Quaternary limestone in Leyte, Philippines. Soil Science, 171(8): 648-661

Asio VB, Jahn R, Perez FO, Navarrete IA \& Abit SM. 2009. A review of soil degradation in the Philippines. Annals of Tropical Research, 31(2):69-94.

Amezketa E. 1999: Soil aggregate stability: a review. J Sustainable Agriculture, 14: 83-151.

Blanco-Canqui $\mathrm{H}$ and Lal R. 2004. Mechanisms of carbon sequestration in soil aggregates. Critical Reviews in Plant Sciences, 23(6):481-504.

Blake GR and Hartge KH. 1986. Methods of soil analysis, Part 1. American Society of Agronomy-Soil Science Society of America, 677 South Segoe Road, Madison, WI 53711, USA.

Bronick CJ and Lal R. 2005: Soil structure and management: a review. Geoderma, 124:3-22.

Carter MR and Stewart BA (eds). 1996. Structure and Organic Matter Storage in Agricultural soils. CSR Press Inc, Boca Raton.

Conant RT, Paustian K \& Elliott ET. 2001: Grassland management and conversion into grassland: Effects on soil carbon. Ecological Applications, 11:343-355.

Dowuona GNN and Adjetey ET. 2010. Assessment of carbon storage in some savanna soils under different land use system in Ghana. Fortaleza, Ceara, Brazil. ICID+18.

Edwards AP and Bremner JM. 1967. Micro-aggregates in soils. J Soil Science, 18 : 64-73. 
Aggregate stability affects carbon sequestration potential

Emerson WW. 1959. Stability of soil crumbs. Nature, 183-538.

Epron D, Marsden C, M'bou AT, Saint-Andre L, D'annunzio R \& Nouvellon Y. 2009. Soil carbon dynamics following afforestation of a tropical savannah with Eucalyptus in Congo. Plant Soil, 323:309-322.

Huygens D, Boeckx P, Van Cleemput O, Oyarz' un C and Godoy R. 2005. Aggregate and soil organic carbon dynamics in South Chilean Andisols. Biogeosciences, 2:159-174.

Intergovernmental Panel On Climate Change (IPCC) 2007. Climate change 2007: The physical science basis. Cambridge University Press, Cambridge.

International Soil Reference And Information Center (ISRIC). 1995. Procedure for Soil Analysis (Van Reuwijk, ed). Wageningen, The Netherlands.

luss Working Group WRB. 2006. World reference base for soil resources. World Soil Resources Report 103, ISSS-ISRIC-FAO, Rome.

Igwe CA, Zarei M \& Stahr K. 2013. Stability of aggregates of some weathered soils in south-eastern Nigeria in relation to their geochemical properties $J$ Earth System Science, 122(5):1283-1294.

Jenkins DS. 1988. The turnover of organic matter in soil. In Wild A (ed), Russell's soil conditions and plant growth (pp564-607). Longman Scientific \& Technical, Harlow.

John B, Yamashita T, Ludwig B \& Flessa H. 2005. Storage of organic carbon in aggregate and density fractions of silty soils under different types of land use. Geoderma, 128:63-79.

Kemper WD and Koch EJ. 1966. Aggregate Stability of soils from the western portion of United State and Canada. U.S. Department of Agriculture Technical Bulletin 1355.

Lal R. 2004. Soil carbon sequestration to mitigate climate change. Geoderma, 123:1-22.

Lal R. 2005. Forest soils and carbon sequestration. Forest Ecology \& Management. 220:242-258.

Lal R. 2008. Carbon Sequestration in soils. CAB international, ISSN 1749-8848.

Lawal HM, Ogunwole JO \& Uyovbisere EO. 2009. Changes in soil aggregate stability and carbon sequestration mediated by land use practices in a degraded dry savanna alfisol. Tropical \& Subtropical Agroecosystems, 10:423 - 429.

Maranguit DS and Asio VB. 2013. Morpho-physical and chemical characteristics of mountain soils in Central Leyte. Annals of Tropical Research, 35(1):35-60.

Marin-Spiotta E, Swanston CW, Torn MS, Silver WL \& Burton SD. 2008. Chemical and mineral control of soil carbon turnover in abandoned tropical pastures. Geoderma, 143: 49-62.

Mbagwu JSC. 2003. Aggregate Stability and Soil Degradation in the Tropics. Lecture given at the College on Soil Physics, Miramare, Trieste, Italy 3-21 LNS0418022. 246-252.

Navarrete IA, Asio VB, Jahn R \& Tsutsuki K. 2007. Characteristics and genesis of two strongly weathered soils in Samar, Philippines. Australian J Soil Research 45(5):153-163. doi:10.1071/SR06103

Navarrete IA, Tsutsuki K, Kondo R \& Asio VB. 2008. Genesis of soils across a late Quaternary volcanic landscape in the humid tropical island of Leyte, Philippines. Australian J Soil Research, 46:403-414 
Navarrete IA, Tsutsuki K, Asio VB \& Kondo R. 2009. Characteristics and formation of rain forest soils derived from late Quaternary basaltic rocks in Leyte, Philippines. Environmental Geology, 58:1257-1268.

Nelson DW and Sommers LE. 1982. Methods of soil analysis, Part 2. American Society of Agronomy-Soil Science Society of America, 677 South Segoe Road, Madison, WI 53711, USA

Tisdall JM and Oades JM. 1982. Organic matter and water-stable aggregates in soils, J Soil Science, 33:141-163.

oades JM. 1984. Soil organic matter and structural stability: mechanisms and implications for management. Plant Soil, 76:319-337.

Onweremadu E, Osuji G, Eshett T, Unamba-Oparah I \& Onwuliri C. 2010. Soil carbon sequestration in aggregate size of a forested Isohyperthermic Arenic Kandiudult. Thai J Agricultural Science, 43(1):9-15.

Percival JH, Roger L, Parfitt AS \& Neal AS. 2000. Factors controlling soil carbon levels in New Zealand Grasslands: Is clay content important? Soil Science Society of America J, 64:1623-1630.

Sanchez PA. 1976. Properties and management of soils in the tropics. Wiley: New York.

Six JH, Bossuyt S, Gryze DE \& Denef K. 2004. A history of research on the link between (micro) aggregates, soil biota and soil organic matter dynamics; Soil \& Tillage Research, 79:7-31.

Šimansky V. 2012. Soil structure stability and distribution of carbon in waterstable aggregates in diff erent tilled and fertilized Haplic Luvisol. Acta Universitatis Agriculturae et Silviculturae Mendelianae Brunensis, 60(3):173-178.

Stockmann U, Adams MA, Crawford JW, Field DJ, Enakaarchchi N, Zimmermann M. 2013. The knowns, known unknowns and unknowns of sequestration of soil organic carbon. Agriculture, Ecosystems \& Environment, 164:80- 99.

Townsend FC and Reeds LW. 1971. Effects of amorphous constituents on some mineralogical and chemical properties of a panamanian latosol. Clays \& Clay Minerals, 19:303-310.

USDA Natural Resources Conservation Service. 2008. Soil Quality Indicators: Aggregate Stability.

Veldkamp E. 2003. Changes in soil carbon stocks following forest conversion to pasture in the tropics, in Notes from Underground: In Holland EA (ed), Soil Processes \& Global Change. Springer Verlag, New York, in press. 